\title{
An Integrated Approach for Long Term Solutions of Flooding: A Study of the Eastern Chitwan Valley
}

Achyut Man Singh

\begin{abstract}
A timeline study since 1976-2010 with satellite imagery maps on the flooding problems of Eastern Chitwan has revealed that due to the rapid degradation of the vegetative cover in the upper catchments of its rivers, increased flooding events had occurred. The conditions of the catchment environment depend on the behavior and activities of the people residing in the area. Infrastructure construction for the flood control in the river banks are short term solutions only effective for a few years. For a long term solution, the people of the area need to be sensitive for the river training works and good watershed management. The study has emphasized social and institutional aspect along with awareness campaign with the populations to achieve good impacts in the long term.
\end{abstract}

Key words: Flood control, watershed management, dykes, spurs, catchments, flood plains, Nepal

\section{Introduction}

The Eastern Chitwan valley is located in the Central Region of Nepal (Figure 1) and has the most ideal environmental friendly surroundings for water and agriculture development if properly protected and conserved. Primary threats to the valley are the aggradations of the streams including the Rapti River due to the changing catchment environment.

The Eastern Chitwan valley has experienced a series of high flood events in the past recalling from $1954 \mathrm{AD}$ (2011 BS), 1971 AD (2028 BS), 1975 AD (2032 BS) and the most damaging flood event of $1993 \mathrm{AD}$ (2050 BS) with loss of 24 lives and 2,206 houses and large scale of properties. After this event, the local communities, and the Government of Nepal (GoN) with the financial assistances of donors such as the Asian Development Bank (ADB), and Swiss Agency for Development and Cooperation (SDC), are taking active lead roles in preventing such disaster by constructing and maintaining the dykes and spurs in the Lothar and Rapti River.

The Chitwan Valley as a whole is ideally set up environmentally by Mother Nature having a National Park in the south, reserve and protected forest cover in the middle, and mixed forest cover in the northern and eastern mountain region.

The study has focused on two aspects: (i) watershed management with livelihood enhancement plan for the hilly catchment of the valley having poor and deprived communities to discourage deforestation and degradation of the watershed and (ii) to prepare a river training master plan for protecting the flood plain area against the flood disaster from the Lothar, Rapti and other streams.

The field works were carried out with intensive consultation with the local communities, including engineering survey works of the rivers and streams. The experts on GIS, Hydrology and Meteorology, Geology, Sociology, and river training have carried out intensive analysis of the field and secondary data from DHM, Survey Department, and Satellite imagery from ICIMOD. GIS and HECRAS software applications were applied from the available satellite imagery, maps and data available from the related agencies in order to prepare distinct workable maps, and to investigate the probable flood prone areas.

\section{Historical Flooding Events and Impacts}

Mustering the time line experiences of the inhabitants of the flood plain areas of the eastern Chitwan Valley it has clearly been revealed that the effect of vegetative environments has a direct impact on the flooding and thus on the settlements with the loss of life and properties. An old man having witnessed the 1993 flood event had told the author that the largest flood event in the Chitwan valley occurred in 1954 AD (2011 BS), when the Rapti and Lothar rivers inundated the whole valley. However, the flood disaster was negligible compared to the 1993 event. He also recalled that the settlements of population were scarce and the environments were covered with thick forest then. During the flooding, water level increased gradually and subsided slowly with mild velocity of flow. But the 1993 flood disaster occurred due to breach of the dyke of the Rapti River, which had swept away large parts of Bhandara, Kumaroj, and Kathar Village Development Committee (VDC) areas adjoining the Dhungre stream taking a death toll of 24 persons and 5,880 no. of livestock, washed out 741 ha, and inundated 2,321 ha of land. The affected households were 5,293 and damaged houses were 2,206 (DWIDP 2009, 2011).

The Kayar Khola stream is the second largest stream in the valley next to the Lothar Khola. The sedimentation problem in this stream also is high, as its river bed up to $7 \mathrm{~km}$ stretch from the foot hill has been covered with debris carried by the stream. Before 1975 $\mathrm{AD}$, the stream banks were covered fully with dense forest and bushes in which the stream was flowing with a stable single channel; while at present, it is covered with sediments and the width of the river bed also has increased to more than $200 \mathrm{~m}$ at places. The local people recall the visible changes in the characteristic of the stream. They said that in the year $1971 \mathrm{AD}$ (2028 $\mathrm{BS}$ ), a large flood event occurred with debris flow and deposited the sediments in the foothill area. Another high flooding event occurred again in 1975 (2032 BS), 


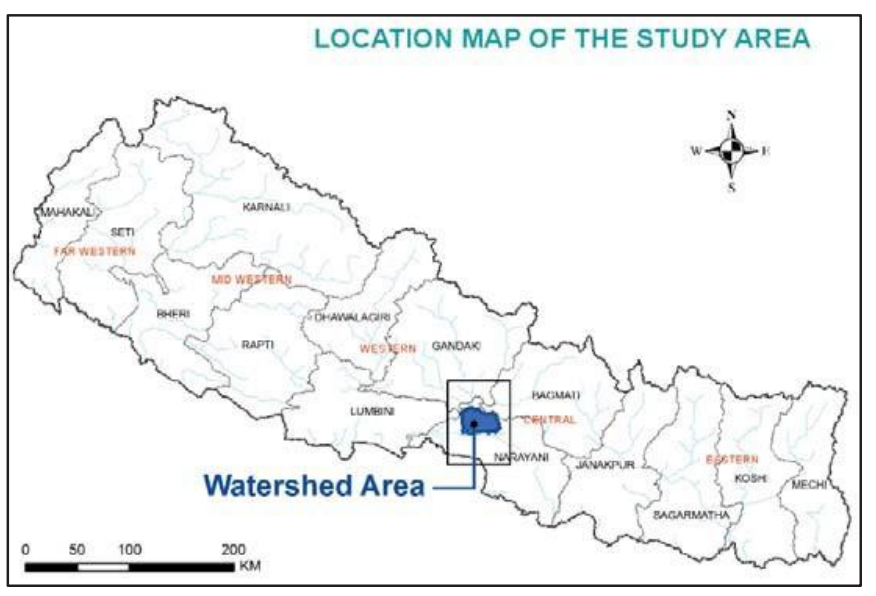

Figure 1. Location Map of the Study Area.
Theoretical Aspects of Flooding and its Origin

The term 'Runoff' is defined as that part of the precipitation that makes its way towards the natural channels, lakes, or oceans as surface or sub-surface flow. It means generally surface water flow in the dictionary. The large flow of water in a stream or rivers due to high precipitation or snowmelt is called 'Flood'. In our sub-continent, the flood events occur during the monsoon season when more than $80 \%$ of the annual precipitation falls. The factors affecting the 'Runoff' or 'flooding' could be grouped into two kinds of physical activities related to: (i) rainfall or precipitation, and (ii) watershed condition. The factors associated with 'Rainfall' are; Rainfall duration, Intensity, and Areal distribution.

which increased the sediment deposition further and inundated the adjacent agricultural lands. The other A rainfall of small duration with the same similar streams such as the Ladara, Chatrang, and Pampa have been subjected to similar changes in their regimes (Please see Figure 3 of Google map for its evidence).

Presently, the Lothar Khola has been identified as one of the most rapidly aggrading rivers in the Terai region of Nepal threatening the East West Highway Bridge, and inundation to the adjacent lands and property. The Department of Water Induced Disaster Prevention (DWIDP) has carried out a detailed study of the watershed conditions to investigate the real cause of the aggradations, which is reported to be in average more

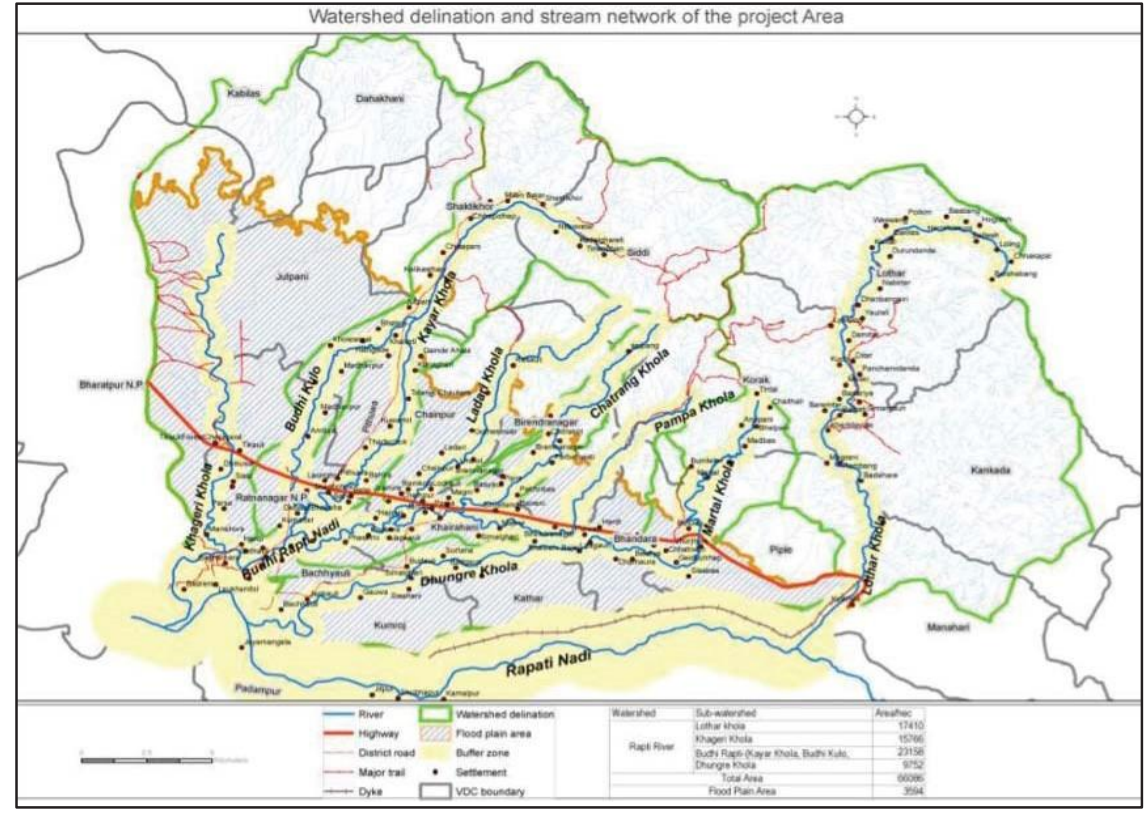

Figure 2. Watersheds in Hills and Flood plain Delineation of Eastern Chitwan Valley.

than 5 to $7 \mathrm{~m}$ at different reaches. The primary causes of the aggradations are uncontrolled deforestation and consequent instability of the prevailing geological formations. Near the Lothar Bridge site of the East West Highway, the river bed has aggraded to more than $5 \mathrm{~m}$ from its base level ${ }^{1}$.

All these events point towards the degradation of the environment and its impacts on the flooding effects. The degradation of the vegetative cover not only causes transportation of large quantity of sediment and debris by rainfall, but also has a direct impact on the volume of the flooding. The effects of such phenomena have been experimentally proved in the USA. Therefore, long term solution of flooding and its disastrous impacts could be reached only if the watershed problems are also addressed and taken care of by restoring/adding to the vegetation cover and improving the environment. intensity will not produce 'Runoff, but for longer duration it will produce 'Runoff. As for smaller duration rainfall, it will be absorbed by infiltration into the groundwater table. Usually intensity of rainfall greater than $37 \mathrm{~mm} / \mathrm{hr}$ produces greater percentage of runoff.

Another main group is 'Watershed' which has also

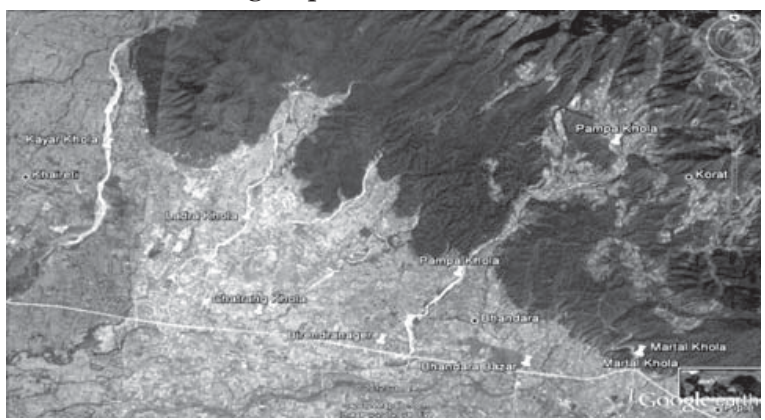

Figure 3. Sediment Deposition by Kayar Khola, Ladari Khola, Chatrang, and Pampa Khola in the Flood Plain. (Source: Google) 
a direct contribution in the runoff volumes. The factors affecting the runoff associated with 'Watershed' are: Size, Shape, Orientation, Topography, and Geology (Soil).

The first group 'Rainfall' related factors are beyond the control of humankind; however, the watershed group can be controlled effectively to reduce or prevent flooding event to some extent only. The experiments conducted in the USA's Iowa and Mississippi watersheds indicated that the runoff occurring from heavy soil is three times larger than in loess soil with the same intensity of rainfall. The effect of land management practices also indicated that the discharge volume varies with the vegetative covers from 2 to 2.5 times with the same amount of rainfall intensity, as indicated in Figure 4. In another experiment, land management in a small watershed of the White Hollow River of 700 ha area was undertaken which has indicated a drastic reduction of runoff to about $15 \%$ only compared to its previous bare soil covered catchment. The effect of land management in small to medium size catchment on runoff is more pronounced,

\section{Rationale for the Study of Flooding}

The event of flooding is an imminent natural phenomenon, which occurs in all the rivers when high intensity rainfall generates surface runoff in the watershed areas. If the flood water confines itself within the active floodplain of the river, it does not have any impact on the settlement and agriculture lands adjacent to its bank. However, the rivers are always prone to outflank the banks as the rainfall patterns are unpredictable; the geological events like earthquakes, landslides, debris flow, and others cause changes in the river regime itself. One has to be prepared for the flood events with preparedness of flood warning system and safe evacuation in case of such events especially during monsoon period in the prevailing climatic set up.

High intensity rainfalls occur frequently in the foothills of the Mahabharat range like Hetauda, Bharatpur, Dharan, Butwal, and also the study area. So, the flood events of unpredictable volume are sometimes

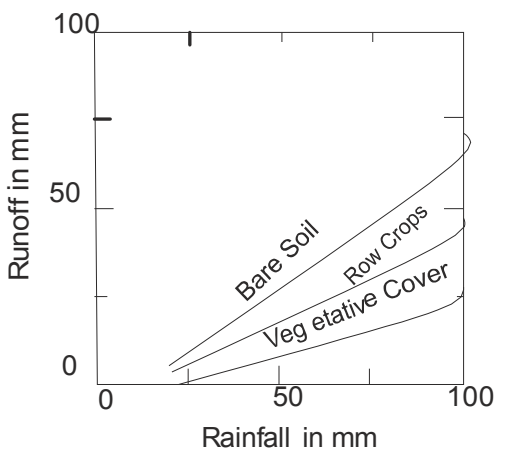

Figure 4. Effect of Vegetative Cover on the Runoff or Flood Volumes. (Source: Soil Conservation and Watershed Management Engineering) imminent and beyond the control of any engineering solution. However, they could be confined to some extent within the flood plain boundary by constructing dykes and other protective measures. One has to accept this fact and should be prepared for its eventuality.

\section{Objectives of the Study}

Overall objective of the study was to find long term solutions to the flooding problems of the Eastern Chitwan Valley

than in larger watershed of rivers

Therefore, vegetative cover of the landscapes is a prominent factor affecting and producing flooding effect.

and to propose an Integrated Watershed Management Plan incorporating the catchment development with a conservation plan and river training plan for the flood plain with engineering solutions.

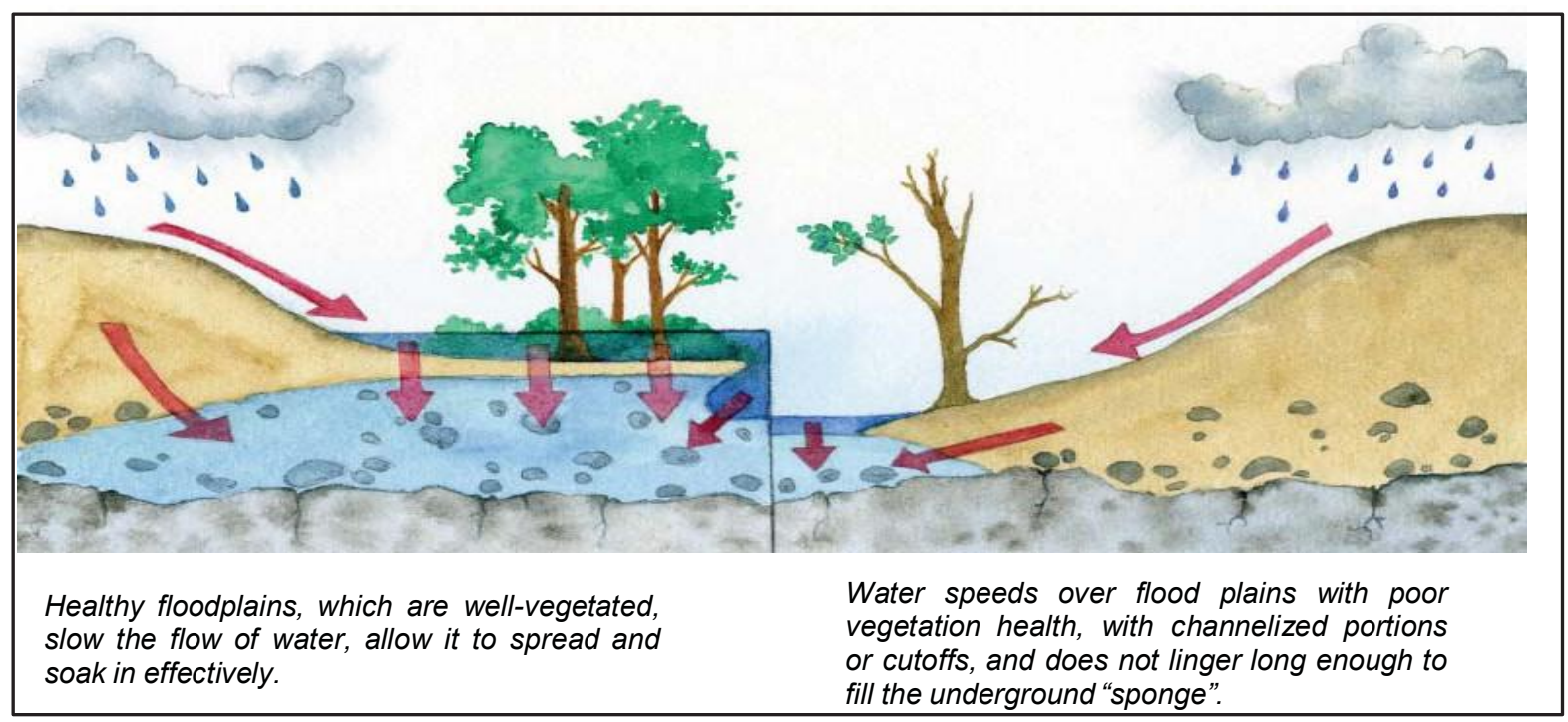

Box 1. Effects of Vegetative and Non-vegetative Catchment Coverage on Environment

Source: Integrated Watershed Management Planning (IWMP), Manitoba Water Stewardship, USA 


\section{Scope of the Study}

The scope of works were envisaged to have in depth analysis of the hydro-metrological conditions, and the land use changes in the watersheds to come up with the long term solutions by collecting available secondary data and the satellite imageries. In brief, the following aspects were covered in the scope of the study.

a. Hydro-Meteorological Study;

b. River System Study;

The river system study was carried out to assess: (i) the flood protection measures along the banks of the rivers and streams, probable vulnerable spots and preventive measures, (ii) watershed Management of the rivers which included the assessment of the catchment conditions, geological events as active slide zone, degradation of the soil cover by deforestation, land use patterns, soil conditions, social structures of the settlements and their cultivation practices such as 'Khoria',

\section{Methodology Applied}

The planning of the study has been conceived to delineate the Eastern Chitwan Valley into two parts as (i) flood plain and (ii) watershed areas in the hills. The flood protection measures will be generally concentrated on the plain areas, whereas soil conservation and protection works in the watershed areas of the hills. The detailed tasks were grouped into sub-tasks as Preparatory works, Field works, Desk works, Interaction and Information Dissemination Works, and Report Finalization and Submission.

The activities as mentioned above were conducted with the team consultation first in the initial stage with literature review and then conceptualizing the details of the works regarding flood management and watershed management. Secondary data analyses of the previous studies were used for modeling the study activities. Geographical Information System (GIS) and Hydro-meteorological analysis were conducted using the prevailing software such as ArcGIS 9.3, EDRASII, and HECRAS to investigate the changes in land use in timeline and flood volume and inundation coverage. The analysis of rivers was conducted using the River Analysis System developed by US Army Corps of Engineers named as HECRAS.

\section{The Study Area}

The study area is bordered in the east by the catchment of the Lothar River, south by the Rapti River, west by the Khageri catchment, and north by the ridge of the Mahabharat mountain range. The study area is comprised of hilly catchment and plain valley as its flood plain having a total area of 661 square kilometre; the plain valley part constitutes 251 square kilometre area of fertile agricultural land, and watershed areas in the hills constitute 410 square kilometre. The Mahendra Reserve Forest and Chitwan National Park covers the valley in the west and south. The study area is composed of one municipality and 16 Village Development Committee (VDC) political boundaries. It constitutes the watershed areas of the adjoining streams - the Lothar, Mardar, Pampa, Chatrang, Ladra, Kayer, Bhudhi Kulo, Khageri and Dhungre Kholas. The proposed study area can be divided in to two parts, as (i) Flood Plain areas and (ii) Catchment areas in the Hills (see Figure 2).

The major land use cover is still the forest lands constituting 54 percent, with cultivation lands of 38 percent as calculated from the topographic map of 1992 imagery (released in 1995). The remaining land cover comprises of bushes, water body and sandy area, and built up areas (SDC 2012).

The Chitwan National Park protects and conserves the forest areas on the left bank of the Rapti River and also its vicinity along the Lothar Rapti Dyke and at Kumaroj VDC at its right bank which are covered with reserve forest as Buffer Zone. The Harda River joins the Rapti River on the left bank just near the confluence of the Lothar River.

The flood plain is a relatively populated area having fertile flat agriculture lands incised by the drains of the rivers and streams, whereas the catchments in the hills are sparsely populated with indigenous tribes and deprived communities.

\section{Climate}

The climate of the Chitwan Valley is classified as subtropical monsoon type with micro-thermal effects in the Mahabharat and Siwalik Hills. The monsoon season (June - September) experiences almost 80-90 percent of the annual rainfall occurrences, which is the main characteristic of the Monsoonal type of climates in the Indian Sub-continent. Orographic effects due to the mountain ranges in the north side of the study area is visibly prevalent in this region as the intensity of rainfall is high compared to other parts of the country.

The annual average rainfall of the study area is about 2,000 $\mathrm{mm}$. The annual mean temperature is about $24^{\circ} \mathrm{C}$ with the highest temperatures occurring in April and May reaching up to $40^{\circ} \mathrm{C}$. The coldest time of the area lies from December to January having lowest value up to $5^{\circ} \mathrm{C}$.

\section{Demography of the Study Area}

The study area of eastern Chitwan is comprised of 16 VDCs and Ratnanagar municipality. Broadly, the study area is divided into watershed area and flood plain area. The total population of the study area is 173,779 (Female 88,163 and Male 85,616) which is approximately $40 \%$ of the district population. The ethnic composition of the study area indicates Brahmin, Tharu, Chhetri, Tamang, Gurung, Newar, Chepang, Kami, Magar, Damai, Kumal, Darai, and other ethnic groups inhabiting the area by maintaining harmonious relationships and engaging in agriculture as well as industrial, and tourism development activities. The ethnic composition of the study area 
is much more similar to the district except for the localization of the Chepang community found largely in Siddi VDC (approx. 90\%) of study area.

\section{Key Findings \\ Changing Land Use Pattern}

Classification of the land use and land cover of the Rapti Watershed of the project area has been assessed using GIS on the topographical map and LRMP map. The calculations of the forest land and cultivation land use with their corresponding VDC are assessed. The findings are given in Table 1. Figure 5 below shows that the forest area has significantly changed during the period 1976 to 1992. The figures indicate that forest land has been encroached for cultivation (SDC 2012).

The land use changes are further analyzed by VDC wise to see which VDC has larger impact of forest encroachment. The forest land in the watershed area particularly in Siddi VDC, Korak VDC, Piple VDC, Lothar VDC, Shaktikhor VDC

\begin{tabular}{|l|c|c|c|c|c|c|}
\hline \multicolumn{2}{|c|}{ Land use LRMP 1976 image } & \multicolumn{2}{c|}{$\begin{array}{c}\text { Land use Topo 1992 } \\
\text { image }\end{array}$} & \multicolumn{2}{c|}{$\begin{array}{c}\text { Changes in 1976- } \\
1992\end{array}$} \\
\hline $\begin{array}{c}\text { Land use } \\
\text { type }\end{array}$ & $\begin{array}{c}\text { Area/ } \\
\text { Sq.Km }\end{array}$ & $\begin{array}{c}\text { Area in } \\
\text { Pecent- } \\
\text { age }\end{array}$ & $\begin{array}{c}\text { Area/ } \\
\text { SqKm }\end{array}$ & $\begin{array}{c}\text { Area in } \\
\text { Pecent- } \\
\text { age }\end{array}$ & $\begin{array}{c}\text { Area/ } \\
\text { SqKm }\end{array}$ & $\begin{array}{c}\text { Area in } \\
\text { Pecent- } \\
\text { age }\end{array}$ \\
\hline Cultivation & 196.9 & $33.8 \%$ & 223.4 & $38.3 \%$ & 26.6 & $4.6 \%$ \\
\hline Forest & 341.0 & $58.5 \%$ & 315.1 & $54.0 \%$ & -26.0 & $-4.5 \%$ \\
\hline Grasslands & 20.1 & $3.4 \%$ & 4.0 & $0.7 \%$ & -16.1 & $-2.8 \%$ \\
\hline Bush & 11.1 & $1.9 \%$ & 12.4 & $2.1 \%$ & 1.3 & $0.2 \%$ \\
\hline $\begin{array}{l}\text { W a t e r } \\
\text { body and } \\
\text { Sandy area }\end{array}$ & 14.1 & $2.4 \%$ & 25.9 & $4.4 \%$ & 11.8 & $2.0 \%$ \\
\hline Built Up & 0.5 & $0.1 \%$ & 0.7 & $0.1 \%$ & 0.2 & $0.0 \%$ \\
\hline Total & 583.0 & $100.0 \%$ & 583.0 & $100.0 \%$ & 82.0 & $14 \%$ \\
\hline
\end{tabular}

Table 1. Changes in Land Use Coverage of the Watershed from 1976-1992.

and Jutpani VDC are observed major encroachment. These VDC are the prime watershed area of Kayer Khola, Pampa Khola, Ladari, and Chhatrang Khola (Table 2).
Land Use Changes in 13 VDCs of Chitwan and Makwanpur Districts from 1992 to 2010

This study carried out a comprehensive analysis of forest area encroachment within the flood plains and watershed boundaries of; namely Kankada, Piple, Manahari, Lothar, Korak, Siddi, Birendranagar, Bhandara, Shaktikhor, Jutpani, Dahakhani, Chainpur and Kabilas VDCs of Chitawan and Makwanpur Districts. In order to calculate the forest encroachment area, the change of forest coverage area of tree and shrub is a fundamental measure over the studied period of time. For this analysis, Landsat TM imagery of 2010, acquired from the ICIMOD, Nepal and Topographic land use digital map, 1992 imagery from the Survey Department, has been used to calculate the encroachment of forest area. The analysis revealed that Jutpani has the highest encroachment area with $16 \mathrm{sq}$. km followed by Kankada and Siddi with 13.6 sq. $\mathrm{km}$ and $12.6 \mathrm{sq}$. $\mathrm{km}$ of forest encroachment areas respectively. As shown in the land classification imagery, forest encroachment in Jutpani VDC is distinctly seen near to the former Maoist cantonment area. Altogether, nearly 109 sq. $\mathrm{km}$ of forest land has been encroached over a period of 18 years within the flood plain boundary of watershed area (Table 2, Figure 6 and 7).

The above analysis made on Landsat TM imagery of 2010, acquired from the ICIMOD, Nepal and Topographic land use digital map, 1992 imagery from survey department, revealed that Jutpani has the highest encroachment area with 16 sq. $\mathrm{km}$ followed by Kankada and Siddi with 13.6 sq.km and 12.6 sq.km forest encroachment area respectively. As shown in

\begin{tabular}{|l|c|c|c|c|c|}
\hline \multirow{2}{*}{$\begin{array}{l}\text { Village Development } \\
\text { Committee (VDC) }\end{array}$} & \multicolumn{5}{|c|}{ Forest Coverage in timeline in the 13 VDCs (Sq. Km) } \\
\cline { 2 - 6 } & LRMP-1976 & TOPO-1992 & $\begin{array}{c}\text { Landsat 2010 } \\
\text { Imagery }\end{array}$ & $\begin{array}{c}\text { Change 1976- } \\
\text { 1992 (16 Yrs) }\end{array}$ & $\begin{array}{c}\text { Change 1992 - } \\
\text { 2010 (8 Yrs) }\end{array}$ \\
\hline Siddi & 42.8 & 36.9 & 24.3 & 5.9 & 12.6 \\
\hline Shaktikhor43.4 & 38.4 & 27.3 & 5 & 11.1 & 9.5 \\
\hline Piple & 28.9 & 24.6 & 15.1 & 4.3 & 11.9 \\
\hline Lothar & 49.1 & 44.8 & 32.9 & 4.3 & 8.4 \\
\hline Korak & 42.4 & 34.2 & 25.8 & 8.2 & 7.1 \\
\hline Kabilas & 16.6 & 16.3 & 9.2 & 0.3 & 6.4 \\
\hline Jutpani39.5 & 33.5 & 17.5 & 6 & 16 & \\
\hline Dahakhani & 21.52 & 0.1 & 13.7 & 1.4 & \\
\hline Chainpur9.5 & 9.4 & 7.9 & 0.1 & 1.5 & \\
\hline Birendranagar & 19.5 & 19 & 13.9 & 0.5 & \\
\hline Bhandara7.6 & 5.1 & 3.8 & 2.5 & 1.3 & \\
\hline KankadaNA & 38.3 & 24.7 & NA & 13.6 & \\
\hline ManahariNA & 8.8 & 4.4 & NA & 4.4 & \\
\hline Total & 320.8 & 329.4 & 220.5 & 38.5 & 108.9 \\
\hline
\end{tabular}

Table 2. Changes in Forest Coverage in the VDCs of the Eastern Chitwan Watershed from 1976 to 1992 and 2010. 

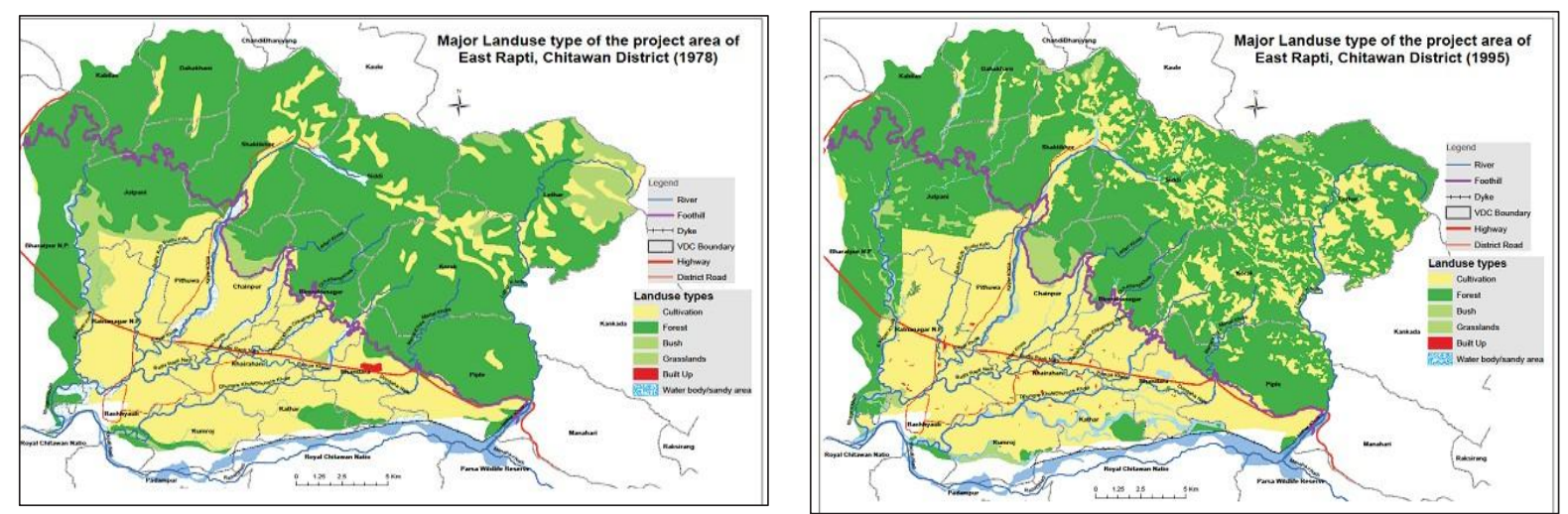

Figure 5. Land Use Type based on the LRMP 1976 Map and 1992 Topographic Map.

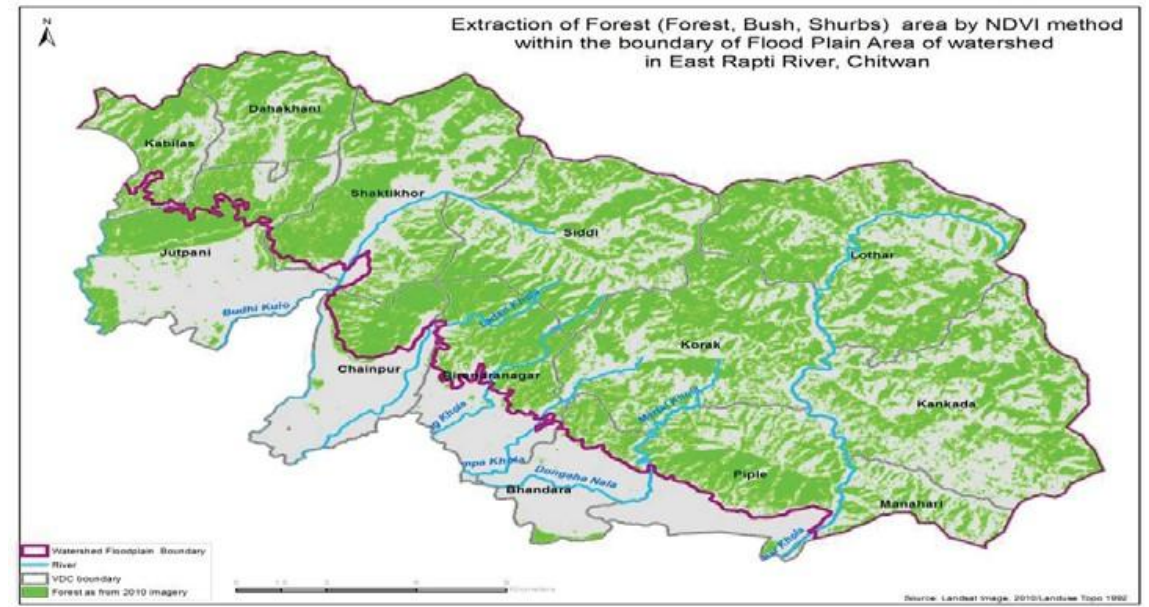

Figure 6. Forest coverage based on the 1992 Imagery. during 50 and 100 year flood volumes (see Figure 8).

Reviewing the landscape and topography of the lower flood plain, Piple, Bhandara, Kathar, Kumaroj, and Bachhauli VDCs are most vulnerable to flood disaster from the Rapti River, as the landforms of these VDCs are sloping from east to west, and lower than the Rapti river bed from the Lothar confluence to the end of the dyke (SDC 2012).

The Lothar-Rapti Dyke is the sole protection measure

classification imagery, the forest encroachment in Jutpani VDC is distinctly seen. Altogether, nearly $109 \mathrm{sq}$. km of forest land has been encroached over the period of 18 years (1992-2010 AD) within the boundary of the watershed area. The very facts indicate the degradation of the environments, as also in the regime and flooding characteristics of the streams and rivers.

\section{Most Vulnerable Areas from Flood Disaster Analysis of Flood Coverage}

The hydrological analysis using HECRAS has revealed that the Rapti River will, most likely, outflank the banks near the

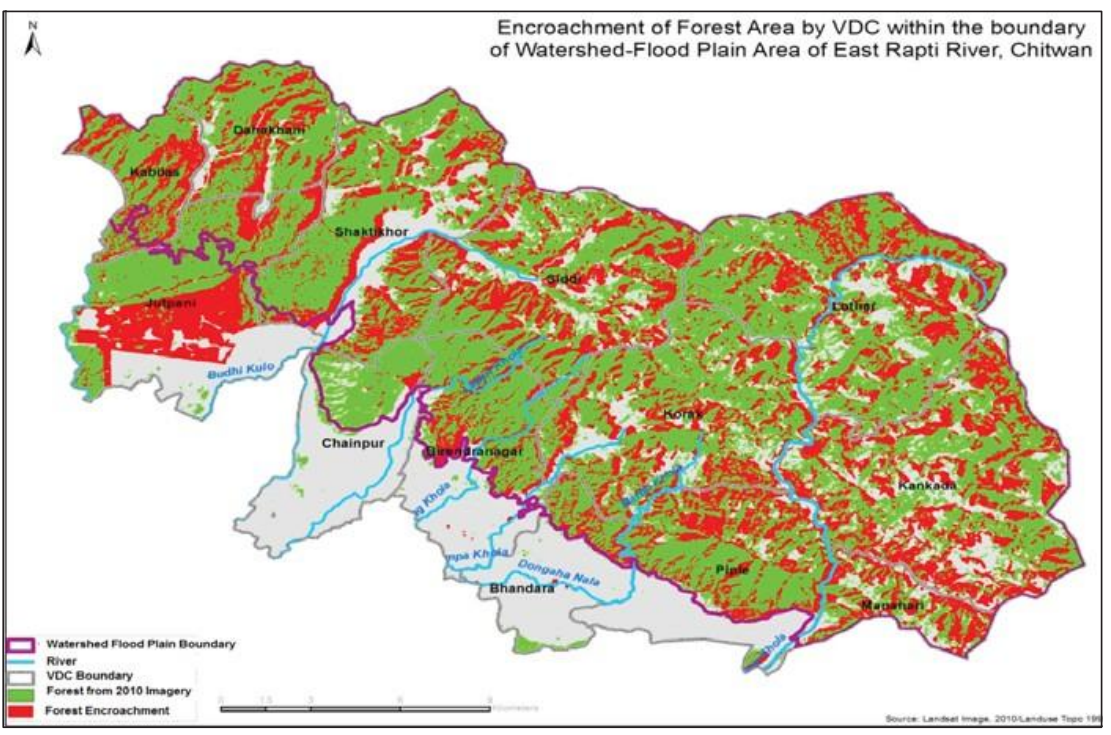
Kumroj and Sauraha area. It has also indicated that some portions of the existing dyke are vulnerable to outflanking by a 100 year return flood; so it has been advised that the Rapti dyke be raised at places. Cases with a similar analysis are adopted in the other streams too, which revealed that adjoining lands are prone to inundation

against flooding in these spots. During monsoon period there is always a high probability that unprecedented rainfall in the Rapti catchment might trigger a high flood and breaching of the embankment. So vigilance and proper preparedness must be taken by the communities to fight against such disaster as in the event of the 


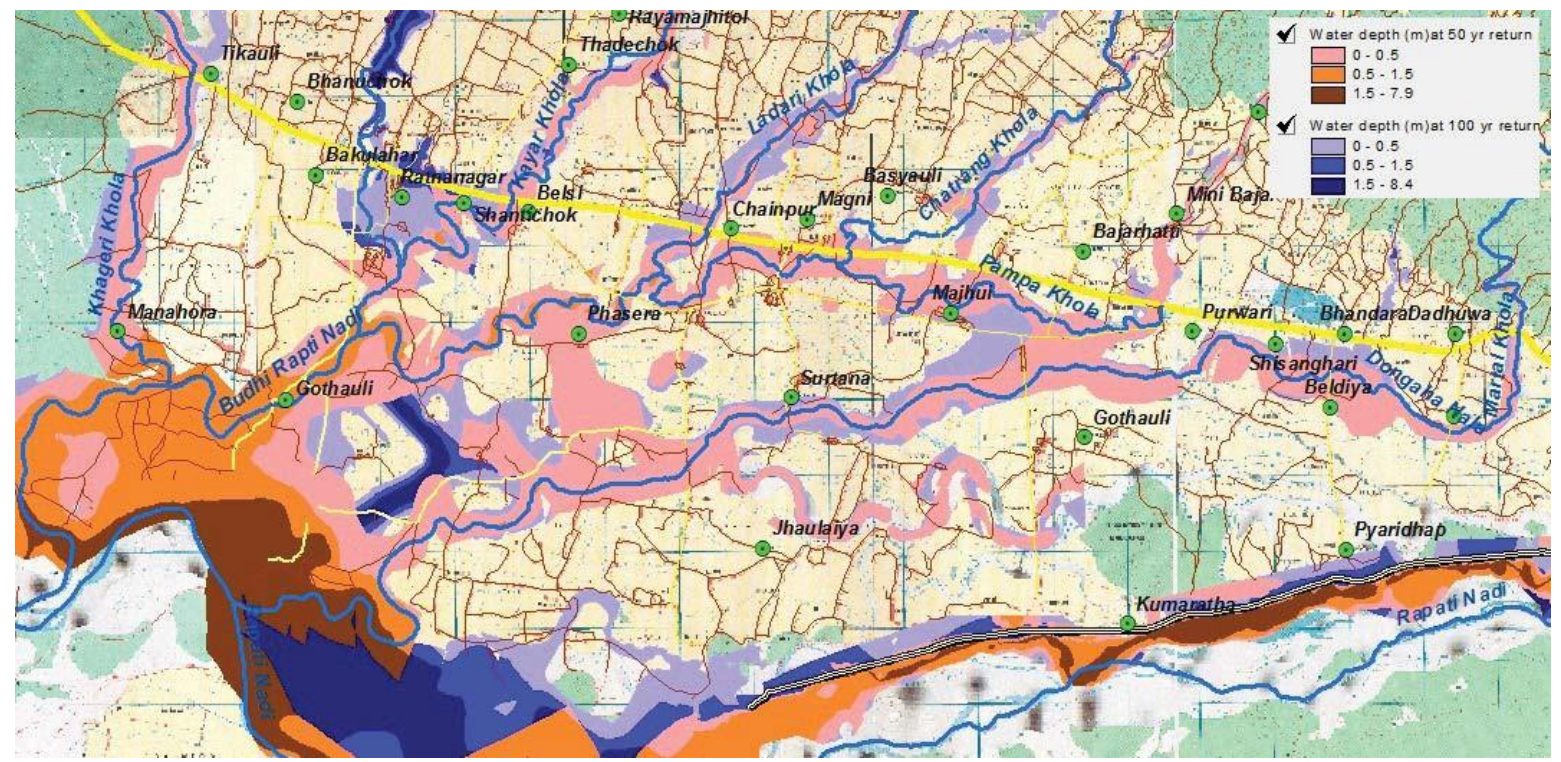

Figure 8. Flood Extent for the Return Period of $50 \mathrm{yrs}$ (Red Color) and 100 years (Blue Color).

1993 flood. The study also has identified that the river is aggrading by 1 to 2 metres on average since the last decade, which will make it most vulnerable to outflanking the existing dyke.

\section{Socio-economic and Institutional Aspects}

Eastern Chitwan Valley has a diversity of ethnic groups, castes, languages and religions, and they have co-existed peacefully since 1956 when the government carried out settlements in the Valley with the Hill migrants to start a better livelihood. It is believed that the Tharus are the oldest ethnic group in the floodplain area; on the other hand, the Chepang, Gurung, Tamang, Magar ethnic groups are the local residents in the hilly areas. The average land holding size in the watershed area is less than 0.5 hectare and the average land holding size in the flood plain is 0.5-1.0 hectare as reported by key informants (SDC 2012).

The DDC Chitwan carried out a study on food sufficiency as a major indicator of poverty in 21 VDCs (total HH 21678) in 2007/o8. As per the study, 29\% of households seem to be vulnerable. During a discussion in February 2012, the key informants of the DDC and VDCs revealed that in the study area approximately $17-20 \%$ of $\mathrm{HH}$ may belong to the below the absolute poverty level as compared to the Per Capita Income level of NRs 15,162 (national level). Further, they expressed that the Hilly VDCs like Lothar, Korak and Siddi etc have the majority of households having to cope with food deficiency, as they can hardly hardly feed themselves for more than 6 months with their regular income.

In the case of the Eastern Chitwan valley, the institution "Lothar Rapti Dyke Protection Committee (LRDPC)" has been active and successful in undertaking protection and maintenance works of the Lothar Rapti Dyke with funding assistance from the SDC. The LRDPC was founded by the flood affected victims who had terrible experiences in the past (1993 Flood), which made them united out of dire necessity to protect their belongings in the future. A common cause holds them together united to form a committee for the welfare of the affected population by irrespective of the ethnic groups and political affiliations. The study has thus proposed the strengthening and reforming of the LRDPC to act as the institution on behalf of the local communities. So, the team has proposed the up-gradation of the LRDPC to assume an active role in the implementation of civil and other works on behalf of the communities as a monitoring body.

\section{Geological Findings}

The rivers, rivulets and streams of the Eastern Chitwan valley originate from the Siwalik and Mahabharat ranges, and traverse through terrain composed basically of sandstone, mudstone and conglomerates of the Siwaliks. The rocks are very fragile in nature. The Mahabharat ranges are comprised of metasedimentary rock and sedimentary rocks like phyllite, slate quartzite and dolomite. The MBT and other thrusts pass too straddle this area. Very few numbers of land slides are seen in the Siwaliks and Mahabharat ranges. There are no conspicuous landslides in Eastern Chitwan valley (SDC 2012).

\section{The River System Analysis}

The Eastern Chitwan Valley is a flood plain being charecherized by the alluvial deposits of the Rapti River and its tributaries like the Lothar, Martal, Pampa, Chatrang, Ladari, Kayar, Khageri, Budhi Rapti Nadi, and Dhongre. The Rapti River flows from the east to west direction at the edge of the study area dissecting the whole Chitwan valley in almost half section. The Rapti River channel is confined in the mountainous area up to say, Hetauda Bazar, braided in the middle reach, and becomes confined into a deep channel 


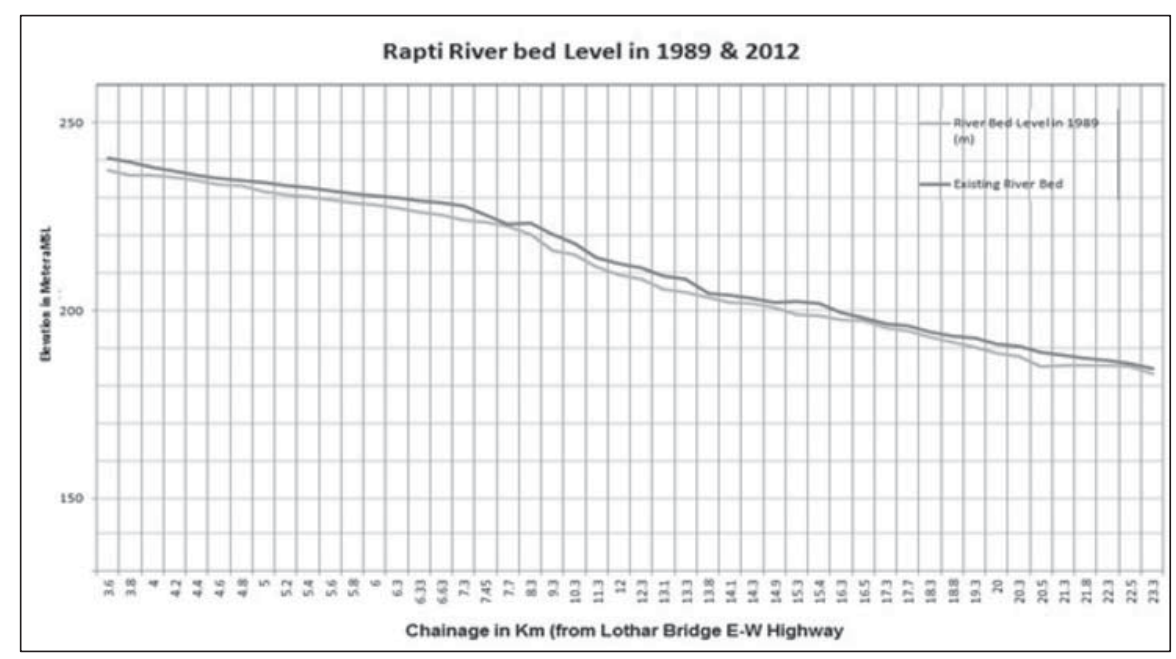

Figure 9. Rapti River Profile Changes from 1989 to 2012. probable such disaster. Its continuous maintenance and strengthening with raising of the embankment height is crucial to prevent breaching in case the anticipated design flood volume is surpassed.

But there remains always the probability that a higher order flood event might occur if unprecedentedly high rainfall events and degradation of its catchment area prevails in future. So both watershed management and river training aspects are important for the long term meandering at the lower reaches, and in meeting its parent channel of the Narayani. The major tributaries are the Manohari, Lothar, Budhi Rapti Nadi, Khageri, and Dhungre streams. Other small tributaries are the Martal, Pampa, Ladari, Chatrang, and Kayar Khola. The major contributors of sediment in the Rapti River are from the tributary streams in Makawanpur district, the Monohari, and Lothar. The channel slope varies from 1 in 240 to 1 in 1240 gradient, and the width of waterway varies from $50 \mathrm{~m}$ to more than $1000 \mathrm{~m}$ depending on the local physiographic set up.

The analysis also has indicated that the Rapti River bed has aggraded from 2 to $3 \mathrm{~m}$ since 1989 to the present study in 2012 (see Figure 9). The aggrading nature of the rivers always threatens to outflank the bank and flooding in the vicinities (Nippon Koie Co. 1989, 1990).

\section{Irrigation Potential in the Valley}

The lower portion of the Eastern Chtwan valley has networks of irrigation systems from the Lothar river, Rapti, Dhongre, Lower Budhi Rapti streams. The irrigation systems are operated and maintained by the farmers with occasional funding from donors or GON. It is noted in the flood plain that the flood control and irrigation systems built in the rivers are interlinked, as water is attracted towards the bank for irrigation purpose, whereas for flood control the rivers are repelled away from the bank.

\section{Effectiveness of the Past and Existing River Training Measures}

The river training works carried out by various agencies, especially the East Rapti Irrigation Project under ADB assistance and LRDPC under SDC assistance, have been most effective in protecting the valley against flood disaster as in 1993.

Among other protection measures in the smaller streams, the Lothar Dyke, and its continuation up to the Rapti Dyke to an extent of $18 \mathrm{~km}$ near Kumroj is most vital and effective against flooding and a cushion of any future safety and sustained stability in the valley (Galay 1994).

\section{Recommendations Integrated Approach}

For a long term solution of the flooding problem, nurturing and proliferating vegetation in the catchment area is a major factor apart from outside human control factors such as rainfall intensity and duration. The local communities should realize this fact and adopt appropriate measures to upgrade the watershed in future, for which the local communities of the watershed have an important role to play. The communities of the flood plain and the watersheds must share and campaign to implement a plan for the preservation of the forests and carry out measures to reduce soil erosion and changing cultivation practices. The study has recommended some plans to develop the institutional set up along with a with livelihood plan for the upper watershed communities.

The condition of the watershed of the Eastern Chitwan valley is at the stage of rapid degradation due to rampant deforestation as the findings of the GIS study reveal. The watershed has been converted to cultivated lands exposing the soil surface, thus triggering high soil erosion and sediment transport in the streams. During interactions and workshops conducted with the communities of the flood plain, these facts have been clearly explained, and they have expressed their commitments to support the communities of the watersheds. The foremost steps for them now are to find a means to stop logging of the forest area, which is in increasing trend.

\section{Watershed Management Aspects}

- Investigation and monitoring of the landslide, debris flow and flood should be carried out on a regular basis especially after the occurrence of events like heavy rain falls, landslides and floods.

- Afforestation in the Churia region and control of deforestation in the Mahabharat region will protect the region from further environmental degradation. 


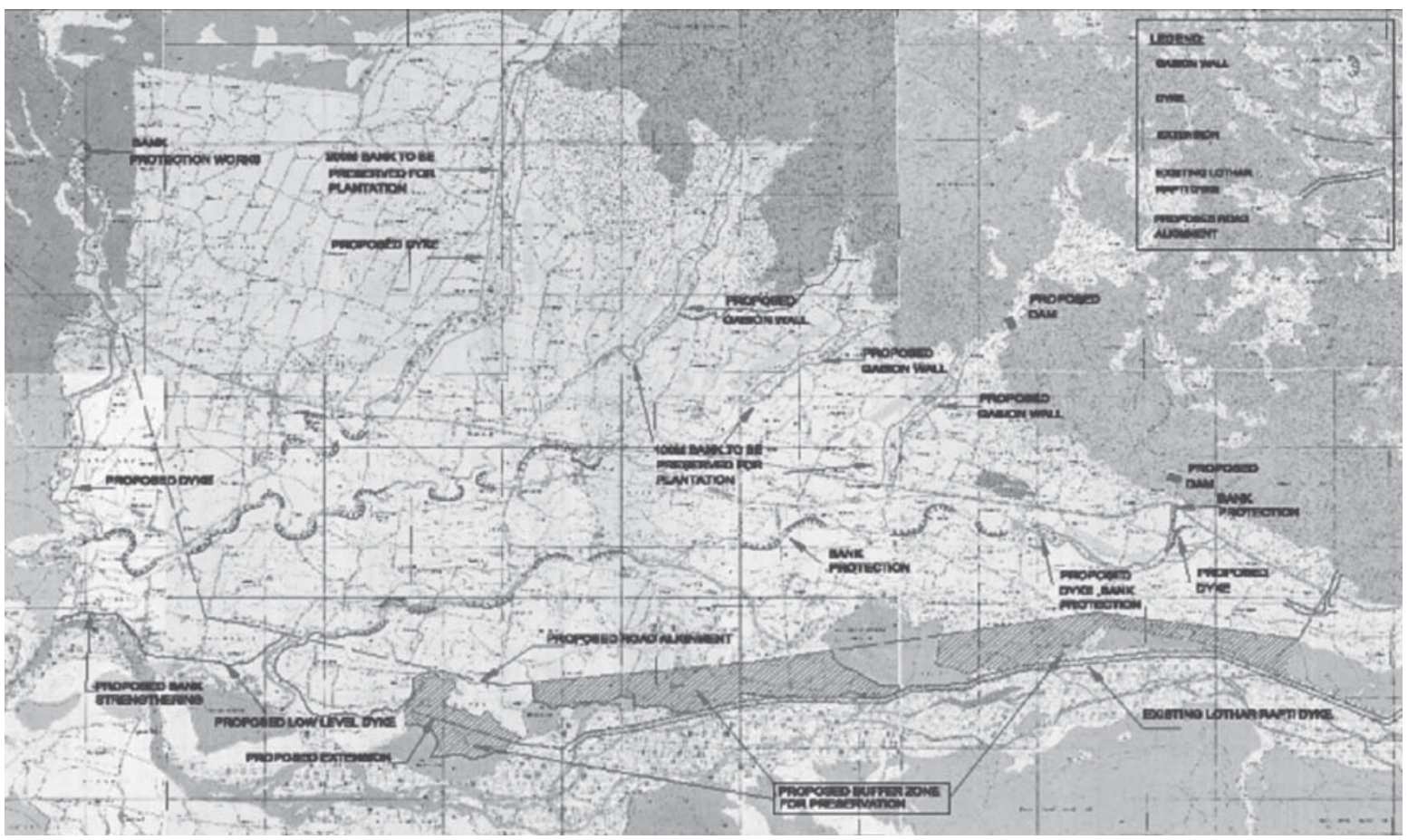

Figure 10. Proposed Medium and Long Term Plan for the Flood Plain of the Eastem Chitwan Valley

A sustainable energy resource management strategy along with diversification of domestic energy from firewood to non-forest products and plantation of trees for fodder and fuelwood will greatly help in protecting the forests in the catchment.

- A public awareness program should be launched in order to disseminate and advocate the causes of disaster occurrence, importance of forest resources and methods to mitigate/protect against disaster.

- Check dams should be made as soon as possible in the riverbed, for instance in the wide valley (e.g., Tangi, Damar, Kuchur, Bangshiling Khola, Ganwarchok Khola sections of the Lothar watershed; Chisapani Khola, Mandu Khola, Khani Khola of the East Rapti River watershed.

\section{Socio-economic Aspects}

- At present the LRDPC is active and functioning well since its establishment and has successfully implemented the river training and irrigation system rehabilitation works in the flood plain under SDC's funding and participatory mode with the communities. The study team has proposed to upgrade and strengthen community institutions in order to enable them to undertake extended responsibilities regarding maintenance of river training and also the watershed management works.

- In order to uplift the living standard of the population of the hilly catchment, a livelihood enhancement plan has been proposed to sensitize and elevate peoples's awareness on the importance of forest cover and guide them towards alternative income generating activities.

\section{Engineering Aspects and Proposed Implementation Plan}

A river training master plan needs to be implemented as a solution to the flooding problem for all the streams/ rivers in the valley by delineating its implementation period as: (i) Short Term (o-5 Yrs), (ii) Medium Term (3-12 Yrs), and (iii) Long Term (5 - 20 Yrs). The proposed engineering protection measures were prepared to address its vulnerability in its site specific situation with its prioritization. The socio-economic and watershed management activities would be carried out in all terms, side by side independently to achieve the impacts on the river behavior (SDC 2012).

\section{Short Term}

The river training works of: (i) Lothar and Rapti Rivers, (ii) SABO dams in Lothar, Martal, Kayar and Pampa, and (iii) low level dyke around Kumaroj and Sauraha areas, are proposed at most vulnerable spots against flooding from the Rapti and Lothar rivers.

\section{Medium Term}

The proposed river training works under this category includes; (i) Kayer Khola (I), (ii) Pampa/Budhi Rapti Nadi (I), (iii) Martal/Dhungre Khola (I), (iv) Construction of Ring Road from Gadaulli to Kathar, Kumroj, Saurah, and Tikauli and (v) plantation in the river/stream banks.

\section{Long Term}

Less vulnerable spots but prone to probable river attacks in future are categorized under this term which would be a guide for future planning. The proposed river training works proposed under this category are; (i) Kayer (II), (ii) 
Pampa/Budhi Rapti Nadi (II), (iii) Martal/Dhungre Khola (II), (iv) Chatrang Khola, (v) Ladari Khola, (vi) Khageri Khola, (vii) plantation and creating buffer zone between the ring road and the Lothar Rapti Dyke, (viii) preservation and maintenance of the river training works.

\section{Acknowledgements}

Mr. Amon Jonchhe of SDC, Mr. Jagrit Prasad Bhetwal and Mr. Lalmani Chaudhary of Lothar Rapti Dyke Protection Committee (LRDPC), Chitwan are greatly appreciated for having initiated and engineered this study.

\section{Financial Assistance}

The study was sponsored by Swiss Agency for Development and Cooperation (SDC) on the request of the community based organization LRDPC. The study was on "Long Term Solution of Flooding in Eastern Chitwan Valley" from January to June 2012 in order to prepare a comprehensive report on watershed management and river training master plan for the flood plain with engineering solution. It was udertaken by SILT Consultant (Pvt) Ltd.

The paper is a synopsis of the detailed study carried out under the sponsorship of SDC.

Achyut Man Singh, BE (Civil), M. Sc. in Soil and Water Management from The Netherlands is an Irrigation Specialist. He served in the Nepal Department of Irrigation for 22 years, and 15 years in the private sector mostly in the field of irrigation engineering. He served a number of assignments for the Asian Development Bank and the World Bank. At present, he is a consultant affiliated with the FAO/WB funded Nepal's Irrigation and Water Resources Management Project. Corresponding address: achyutmsingh@gmail.com

\section{References}

DWIDP, Department of Induced and Disaster Prevention, May, 2011, Study of Lothar Khola Watershed Chitwan/Makwanpur District.

DWIDP, Ministry of Water Resources 2009; "Collection of Disaster Review Regarding to the Project Period of DPTC/DMSP - $1992-2007$.

Galay, VJ , 1994a, Review of Design of Rapti River Flood Rehabilitation Works. Report prepared for East Rapti
Irrigation Project, By Nippon Koi Co Ltd Japan.

Galay, VJ , 1994b, "Morphology of the Dhungre and Budhi Rapti Rivers after 1993 Floods". Report prepared for East Rapti Irrigation Project, By Nippon Koi Co Ltd Japan.

Galay, VJ , 1994c, "Progress of Construction of Flood Protection Dyke". Report prepared for East Rapti Irrigation Project, By Nippon Koi Co Ltd Japan.

Nippon Koei Co. Ltd, Japan, August 1990; Detailed Design Report for Headworks for East Rapti Irrigation Project.

Nippon Koei Col Ltd. Japan, August 1989; "Technical Report East Rapti Irrigation Project Geotechnical Investigation".

Nippon Koei Co. Ltd., Japan, November 1989, "Technical Report for East Rapti Irrigation Project - River Morphology.

Nippon Koei Co. Ltd., Japan, October 1990, "Design Report on Main and Branch Canals Volume-I, Main Report.

Proceeding of National Workshop on "Basin Approach for Soil Conservation and Watershed Management" (June 10, 2010) Ministry of Forest and Soil Conservation - Department of Soil Conservation and Watershed Management. Babar Mahal, Kathmandu.

Swiss Agency for Development and Cooperation (SDC) August 2012, "Study of Long-term Solution of Flooding in Eastern, Chitwan on Request of LotharRapti Dyke Protection Committee, Chitwan”, Volume

I \& II Main Report/Annexes, Kathmandu Nepal. UNDP UN Office for the Co-ordination of Humanitarian, Nepal, December 2003.

Ven Te Chow, David R. Maidment, Larry W Mays, 1988; "Applied Hydrology". McCRAW-HILL International Editions, Civil Engineering Series.

\section{Notes}

1. The base level is an arbitrary river bed level of the Lothar River before the construction of the Highway Bridge - There was a cause way before the construction.

2. Generally "Khoria" in local term indicate cultivation in the existing forest land by clearing and firing the products for cultivation. The people generally cultivate maize in this forest land for maximum of two to three seasons only, when the nutrition is available, and then it is again abandoned.

\section{CALENDAR OF EVENTS - WATER RESOURCES}

Continues from page no. 65

16-20 March, 2013: Transboundary Water Management Across Borders and Interfaces (TWAM) 2013. Location: Aveiro, Portugal. More info: http:// ibtwm.web.ua.pt/congress

22 March, 2013: World Water Day 2013. More info: http://www.unwater.org/watercooperation 2013. html

8-12 April, 2013: India Water Week 2013. Focusing on the theme, "Efficient Water Management: Challenges and Opportunities". Location: India Exposition Mart,
Gautam Budh Nagar, Greater Noida, india. More info: http://www.indiawaterweek.in/html/aboutus. html

23-25 April, 2013: Water Malaysia 2013: International Conference and Exhibition. Location: Kuala Lumpur, Malaysia. More info: http://www.watermalaysia. com/2013/

6-11 May, 2013: Dam Safety Inspection. Location: Trondheim, Norway. More info: http://ich.no/ DynamicCourses.asp?ID $=90$

13-18 May, 2013: World Association of Soil and 